\title{
PERAN PARTAI GOLONGAN KARYA DALAM MELAKSANAKAN PENDIDIKAN POLITIK
}

\author{
(Studi Deskriptif Partai Golongan Karya Kota Serang) \\ M.Triyastono Taufik ${ }^{1)}$, Ujang Jamaludin ${ }^{2)}$, Ronni Juwandi ${ }^{3)}$ \\ Program Studi Pendidikan Pancasila dan Kewarganegaraan, Fakultas Keguruan dan Ilmu \\ Pendidikan, Universitas Sultan Ageng Tirtayasa \\ triyastaufik@gmail.com ${ }^{1)}$,ron.civic90@gmail.com ${ }^{2)}$
}

\begin{abstract}
This studies aim to get knowing that. The Role of Golongan Karya Political Party in The Political Education Implementation. This research held for four month start from December until April 2019. Used on the descriptive method with qualitative approach, data are collected use with interview, observation, and documentation, analysis data collected are following presented taking data, data reduction, data presentation and withdrawal data. Research result indicate theres a trouble from Golongan Karya Political Party (Golkar) in Political Education implementation to society. Political Education implementation do with various methode, theres with visit society door-to-door, sosialization, workshop. Based on research result concluding that an Implementation of Political Education by Golongan Karya Political Party (Golkar) Serang City means to society reinforcement and enhancement quality in order to be political invidual capable.
\end{abstract}

Keywords; Education, Politic, Political Education

\section{PENDAHULUAN}

Undang-Undang Republik Indonesia Nomor 2 Tahun 2011 tentang Partai Politik pasal 1 ayat 4 menyebutkan bahwa "pendidikan politik adalah proses pembelajaran dan pemahaman tentang hak, kewajiban, dan tanggung jawab setiap warga negara dalam kehidupan berbangsa dan bernegara". Disebutkan juga pada pasal 34 ayat 3a yang berbunyi "bantuan keuangan dari Anggaran Pendapatan dan Belanja Negara/Anggaran Pendapatan dan Belanja Daerah sebagaimana dimaksud pada ayat (3) diprioritaskan untuk melaksanakan pendidikan politik bagi anggota partai politik dan masyarakat". Berdasarkan pasal-pasal di atas, dapat dilihat bahwa setiap lapisan masyarakat berhak mendapatkan dan mempelajari pendidikan politik yang diberikan oleh lembaga yang berkewajiban memberikan pengetahuan dan wawasan mengenai pendidikan politik, dan partai politik merupakan salahsatu lembaga penyelenggara pendidikan politik bagi masyarakat. Menurut UU RI Nomor 2 Tahun 2011 tentang Partai Politik pasal 1 ayat 1 menyebutkan bahwa "partai politik adalah organisasi yang bersifat nasional dan dibentuk oleh sekelompok warga negara Indonesia secara sukarela atas dasar kesamaan kehendak dan cita-cita untuk memperjuangkan dan membela kepentingan politik anggota, masyarakat, bangsa dan negara, serta memelihara keutuhan Negara Kesatuan Republik Indonesia berdasarkan 
Pancasila dan Undang-Undang Dasar Republik Indonesia Tahun 1945”.

Aktivitas politik sangat umum adanya di kalangan masyarakat, karena untuk mencapai kesejahteraan dalam hidup yang baik, memperbaiki kondisi, dan status lingkungan yang diakui, memerlukan kegiatan dibidang politik. Menurut Easton (dalam Kartono 2009:15) kehidupan politik itu mengcakup segala aktivitas yang berpengaruh terhadap kebijakan atau policy yang berwibawa dan berkuasa yang diterima oleh suatu masyarakat. Sedangkan menurut Oertzen (dalam Kartono 2009:15) politik merupakan perbuatan intensional, bertujuan, terorganisir, dan mengikuti satu perencanaan pasti, yang teguh memperjuangkan tegaknya, pemeliharaan, dan perubahan suatu pengaturan masyarakat.

Aktivitas politik yang dilakukan oleh masyarakat ini tentunya memiliki dampak yang akan muncul, baik itu positif maupun negatif. Penafsiran masyarakat mengenai politik yang buruk seperti tipu daya, perlakuan kotor, kelicikan, manipulasi, penindasan dan lain sebagainya, jangan sampai terbawa dalam aktivitas politik. Maka dari itu, masyarakat setidaknya harus memahami apa itu dan seberapa penting kah pendidikan politik untuk mengaktualisasikan diri. Pada masyarakat yang tertinggal secara politik, tidak dapat kita temukan suatu proses politik yang maju. Mulai dari individu, kelompok bahkan pemimpin, mereka terlalu mementingkan kepentingannya masing-masing. Masing-masing dari mereka mengejar keinginannya sendiri untuk dicapai dan terkabulkan tanpa mementingkan kepentingan umum. Ini merupakan dampak daripada masyarakat yang terpengaruh oleh negatifnya politik tanpa diimbangi oleh pendidikan politik.

\section{METODE PENELITIAN}

Dalam sebuah penelitian, hal yang tidak boleh terlewatkan diantaranya yaitu metodologi penelitian. Penelitian akan dapat tersusun secara sistematis bila metode yang digunakan sejalan dengan apa yang akan diteliti. Metodologi penelitian menurut Sugiyono (2017:2) merupakan cara ilmiah untuk mendapatkan data dengan tujuan dan kegunaan tertentu. Adapun metodologi penelitian yang akan digunakan oleh peneliti yaitu pendekatan kualitatif dengan menggunakan metode penelitian deskriptif. Menurut Sugiyono (2017:9) dijelaskan bahwa metode penelitian kualitatif adalah metode penelitian yang merujuk pada postpositivisme, digunakan untuk meneliti pada kondisi objek yang alamiah, dimana peneliti berposisi sebagai instrument kunci, teknik pengumpulan data dilakukan secara triangulasi (gabungan), analisis data bersifat induktif/kualitatif, dan hasil penelitiannya yang lebih menekankan makna eksplisit maupun implisit dari pada generalisasi. Selanjutnya dijelaskan menurut Bogdan dan Taylor (dalam Rustanto 2015:17) disebutkan bahwa metode penelitian kualitatif merupakan prosedur penelitian yang menghasilkan data deskriptif berupa kata-kata tertulis atau lisan dari orang-orang dan 
perilaku yang dapat diamati. Metode yang akan digunakan oleh peneliti pada penelitian ini adalah deskriptif, yaitu suatu metode yang memadu peneliti untuk mengeksplorasi dan atau memotret situasi sosial yang akan diteliti secara menyeluruh, luas dan mendalam (Sugiyono, 2009:289). Alasan peneliti menggunakan metode deskriptif dikarenakan peneliti ingin mengambil data secara apa adanya. Artinya, peneliti ingin menggambarkan dan menginterpretasikan data secara real tanpa dibuat-buat. Disini peneliti menggunakan pendekatan kualitatif dikarenakan peneliti ingin mengetahui peran Partai Golongan Karya dalam memberikan pendidikan politik kepada masyarakat di kota Serang secara mendalam.

\section{Pendekatan Penelitian}

Berdasarkan judul yang peneliti ambil, maka pendekatan yang digunakan oleh peneliti yaitu pendekatan kualitatif. Pendekatan kualitatif merupakan metode baru, karena popularitasnya belum lama, dinamakan metode post positivistik karena berlandaskan pada filsafat post positivisme (Sugiyono, 2017:7).

\section{Jenis Penelitian}

Jenis penelitian yang akan digunakan oleh peneliti adalah jenis penelitian deskriptif. Data yang akan peneliti kumpulkan melalui jenis penelitian deskriptif ini ialah data wawancara, dokumentasi dan observasi.

\section{Fokus Penelitian}

Memberikan pendidikan politik merupakan salah satu kewajiban yang harus dilaksanakan oleh setiap partai politik. Seperti yang terdapat pada Undang-Undang Republik Indonesia Nomor 2 Tahun 2011 tentang Partai Politik pasal 1 ayat 4 menyebutkan bahwa "Pendidikan Politik adalah proses pembelajaran dan pemahaman tentang hak, kewajiban, dan tanggung jawab setiap warga negara dalam kehidupan berbangsa dan bernegara".

\section{Prosedur Pengumpulan Data}

Dalam penelitian kualitatif, pengumpulan data dilakukan pada natural setting (kondisi yang alamiah), sumber data primer, dan teknik pengumpulan data lebih banyak pada observasi berperanserta, wawancara mendalam dan dokumentasi (Sugiyono, 2017:225).

Prosedur pengumpulan data pada penelitian ini dimulai dari prapenelitian yaitu untuk mengetahui peran partai politik dalam melaksanakan pendidikan politik di masyarakat. Prosedur yang digunakan adalah untuk mengetahui apakan partai politik sudah memberikan pendidikan politik kepada masyarakat dengan baik. Prosedur pengumpulan data merupakan langkah yang paling strategis dalam penelitian, karena tujuan utama dari penelitian adalah mendapatkan data, tanpa mengetahui teknik pengumpulan data, 
maka peneliti tidak akan mendapatkan data yang memenuhi standar data yang ditetapkan (Sugiyono, 2012:224).

Untuk menggali lebih dalam mengenai pendidikan politik yang diberikan oleh partai politik tersebut, maka diperlukan wawancara terhadap partai politik maupun juga masyarakat, hal ini dilakukan guna menunjang validasi data yang ingin diperoleh. Selain itu, untuk mengamati kesesuaian/validasi antara partai politik dan masyarakat, perlu dilakukan juga observasi langsung ke lapangan. Dari kegiatan-kegiatan yang dilakukan tadi, untuk lebih mendukung validasi data yang telah diperoleh, maka diperlukan juga sebuah dokumentasi selama penelitian ini berlangsung.

a. Wawancara

Stainback (dalam Sugiyono 2017:232) mengemukakan bahwa:

"interviewing provide the researcher a means to gain a deeper understanding of how te participant interpret a situation or phenomenon than can be gained through observation alon". Jadi dengan wawancara, maka peneliti akan mengetahui hal-hal yang lebih mendalam tentang partisipan dalam menginterpretasikan situasi dan fenomena yang terjadi, dimana hal ini tidak bisa ditemukan melalui observasi. b. Observasi

Nasution (1988) menyatakan bahwa observasi adalah dasar semua ilmu pengetahuan. Sedangkan Marshall (1955) menyatakan bahwa "through observation, the researcher learn about behaviour and the meaning attached ti those behaviour". Melalui teknik ini, peneliti berusaha menemukan makna tentang perilaku dan pola pikir yang dihasilkan dari perbuatan, serta makna ekplisit dan implisit dari perilaku tersebut (Sugiyono, 2017:226).

c. Dokumentasi

Menurut Sugiyono dokumen merupakan catatan peristiwa yang sudah berlalu. Dokumen bisa berbentuk tulisan, gambar, atau karyakarya monumental dari seseorang. Dokumen yang berbentuk tulisan misalnya catatan harian, sejarah kehidupan, deskripsi historiografi, biografi, peraturan, maupun kebijakan pemerintah apapun bentuknya. Studi dokumen merupakan pelengkap dari penggunaan metode observasi dan wawancara dalam penelitian kualitatif.

\section{Analisis Data}

Setelah semua data-data yang dicari sudah terkumpul dan dapat diolah, maka langkah selanjutnya adalah analisis data. Menurut Bogdan (dalam Sugiyono 
(2009:334) anlisis data adalah proses mencari dan menyusun secara sistematis data yang diperoleh dari hasil wawancara, catatan lapangan dan bahan-bahan lain, sehingga dapat mudah dipahami, dan semuanya dapat diinformasikan ke orang lain.

Dalam proses penelitian ini, peneliti menggunakan teknik analisis data dengan model Miles dan Huberman. Setelah peneliti mengumpulkan data, langkah selanjutnya menurut Miles dan Huberman adalah: (1). Reduksi Data, (2). Penyajian Data, dan (3). Verifikasi.

6. Pemeriksaan Atau Pengecekan Keabsahan Data

Pengujian Validitas dan Reliabilitas sangat diperlukan dalam sebuah penelitian, hal ini berkenaan dengan apakah sebuah penelitian dapat dikatakan layak atau tidak. Untuk menguji kredibilitas penelitian ini, peneliti menggunakan teknik Triangulasi. Menurut Sugiyono (2017:241) menyatakan bahwa, "dalam teknik pengumpulan data, triangulasi diartikan sebagai teknik pengumpulan data yang bersifat menggabungkan dari berbagai teknik pengumpulan data dan sumber data yang telah ada". Peneliti mengambil ketiga triangulasi untuk melakukan pengecekan keabsahan data, yaitu triangulasi sumber, triangulasi waktu dan triangulasi teknik.

\section{HASIL PENELITIAN DAN PEMBAHASAN}

Berdasarkan hasil wawancara dari beberapa responden partai politik dan beberapa responden masyarakat di atas, dapat dilihat bahwa peran partai politik dalam memberikan pendidikan politik kepada masyarakat sudah berjalan walaupun belum maksimal. Dapat dilihat sudah banyak masyarakat yang sadar akan politik, dan banyak pula masyarakat yang meninggalkan pemikiran bahwa politik itu tidak baik. Dalam hal ini, ada banyak proses yang dilakukan partai politik Golkar dalam menjadikan pendidikan politik dapat tersampaikan kepada masyarakat, dari mulai mendatangi kesetiap kecamatan maupun desa yang ada di Kota Serang, sampai mengadakan sosialisasi pendidikan politik kepada masyarakat. Dengan melakukan tatap muka secara langsung kepada masyarakat, diharapkan partai Golkar dapat menjalankan tugasnya sebagaimana amanat dari UU dalam memberikan pendidikan politik kepada masyarakat, walaupun didalam pelaksanaannya partai Golkar mendapatkan berbagai masalah, akan tetapi Partai Golkar tetap berusaha dalam upaya memberikan pendidikan politik kepada masyarakat ini.

Pelaksanaan pendidikan politik menjadi tanggung jawab secara khusus untuk meningkatkan kualitas dan pengetahuan masyarakat tentang politik. Berdasarkan data yang diperoleh melalui hasil wawancara mengenai pendidikan politik 
yang diberikan oleh partai politik, peneliti mendapatkan persepsi mengenai pendidikan politik menurut berbagai responden, yaitu dari partai politik dan juga dari responden masyarakat. Berdasarkan hasil beberapa responden berpendapat bahwa partai Golkar sendiri tidak membeda-bedakan golongan, semua lapisan masyarakat wajib diberikan pendidikan politik dan mendapatkan pendidikan politik. Karena sebagai partai politik yang merupakan lembaga politik wajib memberikan pendidikan politik kepada masyarakat. Supaya kedepannya masyarakat tidak mudah dibodohi mengenai politik, dan sadar akan proses politik. Hal ini sesuai dengan teori yang dikemukakan oleh Kartono (2009:64), pendidikan politik adalah upaya edukatif yang internasional, disengaja dan sistematis untuk membentuk individu sadar politik, dan mampu menjadi pelaku politik yang bertanggung jawab secara etis atau moral dalam mencapai tujuan-tujuan politik. Selain itu pendidikan politik adalah suatu proses untuk menjadikan masyarakat yang cerdas dalam politik, demi kesejahteraan berbangsa dan bernegara. Pendidikan menjadikan manusia kearah yang maju, lalu dapat menjamin hidup bermasyarakat dan juga aktivitas politik. Politik yang lahir dikalangan masyarakat mempunyai berbagai dampak, baik itu dampak positif maupun negatif. Pendidikan politik adalah solusi untuk mencerdaskan masyarakat, menjadikan aktivitas politik dapat terarah, dan selanjutnya dapat dilaksanakan kedalam hidup bermasyarakat.

Memberikan pendidikan politik kepada masyarakat merupaka salah satu tanggung jawab semua partai politik. Proses pelaksanaan pendidikan poltik yang dilakukan oleh partai Golkar sebenarnya sudah dengan baik dilakukan kepada masyarakat, akan tetapi terdapat berbagai hambatan yang dihadapi dalam pelaksanaannya sehingga membuat hasil yang didapatkan untuk menjadikan masyarakat pintar akan politik kurang maksimal. Kendala-kendala tersebut salah satunya datang dari masyarakat yang tidak mau diberikan pendidikan politik karena masyarakat menilai bahwa politik adalah hal negatif yang kegunaannya untuk merebut kekuasaan saja. Pandangan mengenai buruknya politik tentunya berdampak kepada sebuah partai politik, yang menjadikan terhambatnya kedekatan partai politik dengan masyarakat. Banyaknya pula pemberitaan tentang survei yang menyebutkan bahwa masyarakat tidak percaya akan partai 
politik, memperparah keadaan politik pada saat ini.

Untuk solusi dari setiap hambatan yang ada, partai Golkar mempunyai cara yang dapat dilakukan, pertama beruhasa untuk menjaga citra partai Golkar dihadapan masyarakat, dengan terus melakukan kegiatan-kegiatan kemasyarakatan sesuai dengan visi dan misi, juga sesuai dengan panca bhakti partai Golkar. Kedua melakukan kedekatan dengan masyarakat melalui program door to door, dengan langsung bertatap muka dengan masyarakat, dan juga langsung memberikan pendidikan politik kepada masyarakat, yang diharapkan masyarakat dapat memahami pendidikan politik secara mendalam.

\section{KESIMPULAN}

Berdasarkan penelitian yang saya lakukan mengenai peran partai Golongan Karya dalam melaksanakan pendidikan politik, dapat disimpulkan bahwa:

1. Pelaksanaan pendidikan politik yang dilakukan oleh partai Golongan Karya kepada masyarakat sudah berjalan dengan baik, akan tetapi belum maksimal dalam pelaksanaannya. Banyak faktor yang mempengaruhi dalam upaya memberikan pendidikan politik kepada masyarakat, yang salah satunya datang dari masyarakat. Dalam aktivitas politik, masyarakat sudah dapat menjadi insan yang demokratis, menjadikan pendidikan politik sebagai landasan dalam politik, dan juga dapat merealisasikan dirinya baik dalam sosial masyarakat maupun dalam politik, yang aspirasinya dapat diwakilkan oleh partai-partai politik yang ada.

2. Terdapat hambatan yang dihadapi oleh partai Golkar dalam memberikan pendidikan politik, diantaranya yaitu dari masyarakat yang memilih untuk apatis terhadap politik, apatis terhadap partai politik, sampai masyarakat yang belum sadar akan pentingnya pendidikan politik dalam aktivitas politik. Solusi yang dilakukan partai Golongan Karya dalam memberikan pendidikan politik kepada masyarakat berkaitan dengan bagaimana penyampaian dan pelaksanaannya. Partai Golkar memberikan penjelasan secara mendalam, dan juga teratus setiap tiga bulan sekali. Metode yang dilakukan agar sasarannya tertuju dengan baik dengan cara pintu ke pintu atau dengan kata lain langsung menemui masyarakat yang dirasa kurang memahami pendidikan politik.

\section{DAFTAR PUSTAKA}

Kartono, Kartini. 2009. Pendidikan Politik. Bandung. Mandar Maju.

Rustanto, Bambang. 2015. Penelitian Kualitatif Pekerjaan Sosial. Bandung. PT Remaja Rosdakarya. 


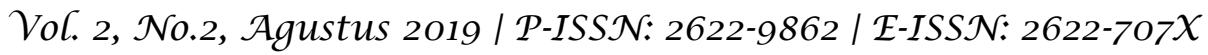

Sugiyono. 2009. Metode Penelitian

Pendidikan Pendekatan Kuantitatif,

Kualitatif dan R\&D. CV Alfabet

Sugiyono. 2017. Metode Penelitian Kualitatif,

Kuantitatif, dan $R \& D$. Bandung. CV

Alfabeta.

Undang-Undang Republik Indonesia Nomor 2

Tahun 2011 Tentang Perubahan Atas Undang-

Undang Nomor 2 Tahun 2008 Tentang Partai

Politik. 